\title{
Manchas Mongólicas Múltiplas e Sobrepostas numa Criança Caucasiana
}

\author{
Ana Marta António', Adelina Costin², Henriqueta Cunha ${ }^{3}$ \\ 'Interna do Internato de Formação Específica em Dermatovenereologia; Serviço de Dermatovenereologia, Hospital Garcia de Orta, \\ Almada, Portugal \\ ${ }^{2}$ Interna do Internato de Formação Específica em Dermatovenereologia; Serviço de Dermatovenereologia, Hospital Garcia de Orta, \\ Almada, Portugal \\ ${ }^{3}$ Assistente Hospitalar Graduada em Dermatovenereologia \\ Serviço de Dermatovenereologia, Consulta de Dermatologia Pediátrica, Hospital Garcia de Orta, Almada, Portugal
}

RESUMO - A mancha mongólica é uma forma de melanose dérmica comum em recém- nascidos, tendo uma incidência e prevalência variável consoante a raça, sendo menos frequente em crianças caucasianas. Apesar de tradicionalmente interpretadas como benignas, várias publicações têm vindo a sugerir que manchas mongólicas extensas, múltiplas, presentes em locais atípicos e persistentes ao longo da primeira infância podem estar associadas a algumas doenças metabólicas. Contudo, esta associação não está ainda bem esclarecida. Por outro lado, casos pontuais reportados na literatura têm descrito um tipo particular de mancha mongólica sobreposta a outra de pigmentação diferente, não sendo conhecido o mecanismo fisiopatológico e a relevância clínica deste achado. Os autores reportam o caso de um rapaz caucasiano com 7 meses de idade com manchas mongólicas múltiplas, extensas, de agravamento progressivo nos primeiros meses de vida, uma das quais mais pigmentada sobreposta a outra, localizada na anca direita.

PALAVRAS-CHAVE - Grupo de Ascendência do Continente Europeu; Lactente; Mancha Mongólica; Nevo Pigmentado.

\section{Multiple and Superimposed Mongolian Spots in a Caucasian Child}

ABSTRACT - Mongolian spots are common birthmarks in newborns and their incidence and prevalence vary considerably between races, being the lowest in caucasian infants. Although traditionally regarded as benign, some reports suggested that extensive and multiple mongolian spots at aberrant locations and persistent beyond early childhood may co-exist with inborn errors of metabolism. However, this association is not well established. Besides, very few cases in literature reported a particular type of superimposed mongolian spots, whose physiopathological mechanism and clinical significance are unknown. We report a case of a 7-months-old caucasian male infant with multiple, extensive and progressive mongolian spots and also a superimposed mongolian spot located on the right hip.

KEYWORDS - European Continental Ancestry Group; Infant; Nevus, Pigmented; Mongolian Spot.

\section{INTRODUCTION}

Mongolian spots (MS) are common birthmarks in newborns whose incidence and prevalence vary considerably between races, being the lowest in caucasian infants, about $10 \%$. They are non-blanching hyperpigmented grayish macules or patches localized to the gluteal region usually present at birth or in first few weeks of life. ${ }^{1}$ Typically they can vary in shape and size but pigmentation is usually homogenous. Although traditionally regarded as benign, some publications suggested that extensive and multiple MS present at aberrant locations and persistent beyond early childhood may co-exist with inborn errors of metabolism. ${ }^{2-5}$ The most common lysosomal storage disorders associated with MS are mucopolysaccharidosis type I (Hurler's disease)
Correspondência: Ana Marta António

Av. Torrado da Silva

2801-951 Almada, Portugal

E-mail: anamartaantonio@gmail.com
Recebido/Received

15 Março/March2017

Aceite/Accepted

20 Maio/May 2017 


\section{Caso Clínico}

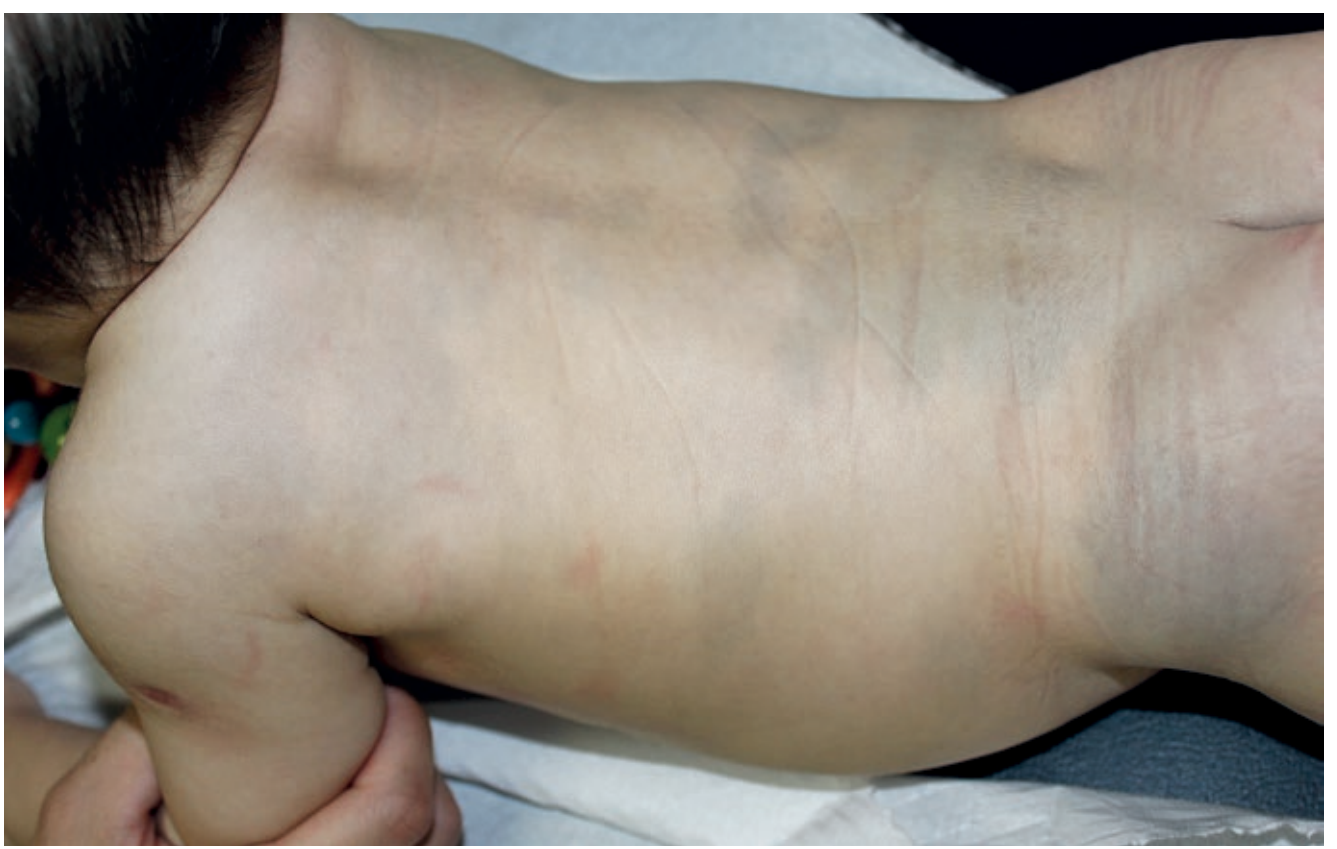

Figure 1 - Multiple MS involving gluteal, sacrococcygeal areas and lower, middle and upper trunk.

and GM1-gangliosidosis, and in a few cases mucopolysaccharidosis type 2 (Hunter's syndrome), mucolipidosis, Niemann-Pick disease and mannosidosis. ${ }^{2-7}$ The pathogenic mechanisms behind this association are not completely understood but metabolites accumulated in inborn errors of metabolism seem to have an important role: they bind to a tyrosine kinase-type receptor and result in an abnormal activity of nerve growth factor, an important signal for transdermal melanocyte migration. ${ }^{2,4}$
The association of persistent or aberrant MS with vascular birthmarks like aberrant nevus flammeus and pigmentary abnormalities in phakomatosis pigmentovascularis, or in some cases of Sturge-Weber syndrome, Klippel-Trenaunay syndrome and cutis marmorata telangiectatica congenita, is better established. ${ }^{8-10}$ In these situations, apart from the MS, there are other physical signs which raise the suspicion of the existence of a congenital disorder and a clear need of additional investigations.

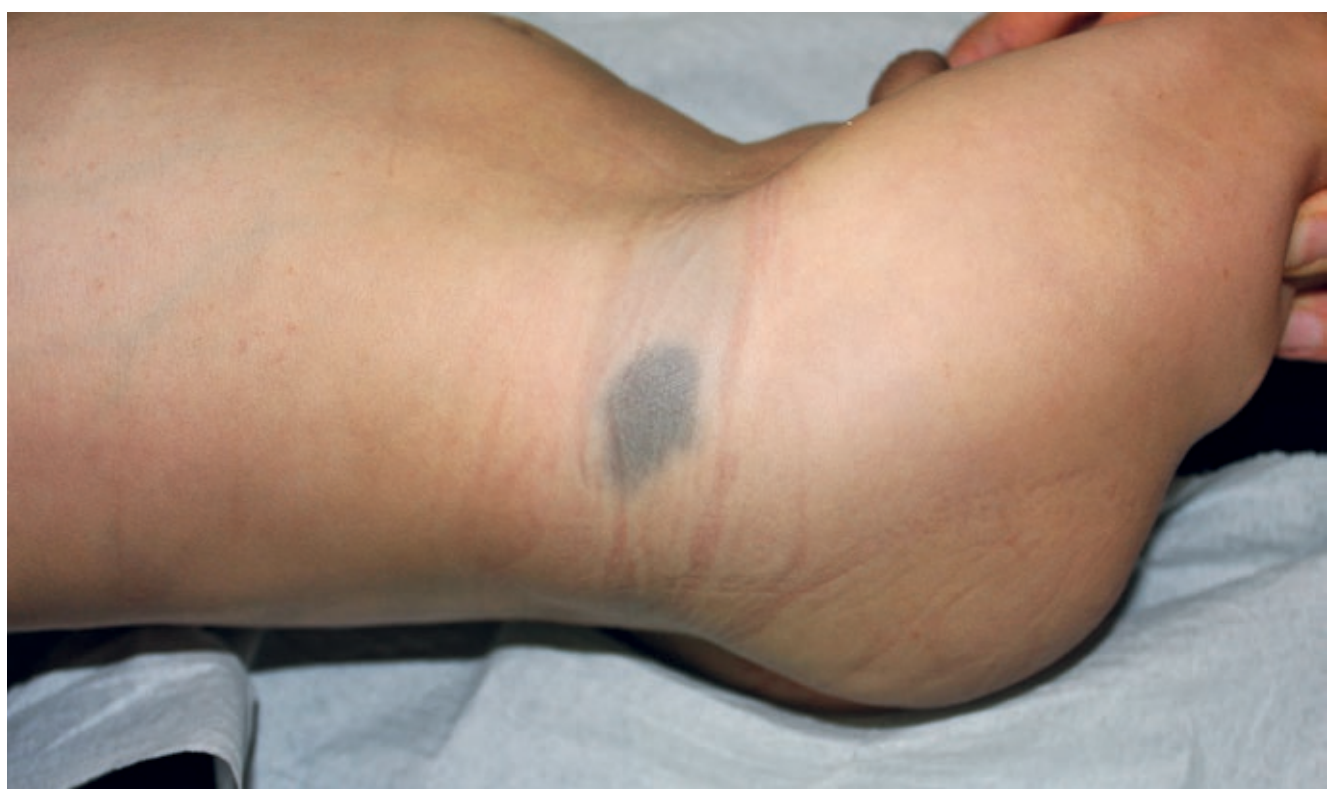

Figure $\mathbf{2}$ - Superimposed MS on lateral aspect of the right hip. 
In the absence of other abnormalities, the main difficulty is to select which cases of MS should be further investigated to rule out a congenital metabolism disorder, and which diagnostic investigation protocol should be adopted. There are no established and consistent clinical guidelines about this issue.

\section{CASE REPORT}

We report the case of a 7 -months-old white male infant with multiple and aberrant MS refered to a Pediatric Dermatology consultation by the Pediatrician. Dermatological examination showed a large grey ill-defined patch involving the lumbar, sacrococcygeal and gluteal areas (size $10 \times 11 \mathrm{~cm}$ ); multiple satellite smaller light-grey macules and patches on the middle and upper back involving both scapular areas (Fig. 1); and a dark grey coin-shaped spot (size $3 \times 2 \mathrm{~cm}$ ) on the lateral aspect of the right hip over a very light-grey ill-defined patch involving the right hip line and ipsilateral inguinal region (Fig. 2). According to the parents these patches were present at birth and became more evident during first months of life. The examination was otherwise unremarkable with no hepatosplenomegaly or musculoskeletal abnormalities. After being informed of the probable diagnosis of MS and once the child was healthy the parents denied permission to perform a skin biopsy. A clinical diagnosis of multiple and superimposed MS was made. There was no history of complications during pregnancy or the neonatal period. There was no history of consanguinity or genetically transmitted diseases within the family. Physical growth and psychomotor development were normal. Attending to this, despite the absence of other signs, with such an atypical MS in a caucasian child, we decided to ask for a Neuropediatrician opinion. Neurological examination was completely normal therefore no additional test was requested to exclude neurologic involvement as after a perfectly normal physical and neurological examination, the coexistence of an inborn error of metabolism is very unlikely. This child maintains a close clinical follow-up in the outpatient Pediatric Clinic and no development or physical abnormality was found until the age of 2 years. Mongolian spots are persistent but tend to become clearer and less evident.

\section{DISCUSSION}

Mongolian spots can no longer be considered always as benign. When MS are extensive, multiple, progressive, involve unusual locations (dorsal and ventral aspects of trunk, extremities) and have a darker pigmentation are suspicious of the coexistence of a storage disorder. ${ }^{3,11}$ A prospective study showed that these characteristics are associated with persistence of MS beyond 1 year and suggest that in these cases babies should be screened for disorders of metabolism. ${ }^{11}$ Nevertheless this association is not well established and can not be regarded as a rule. In our case, besides the presence of aberrant MS in a caucasian infant, no abnormality was found until this moment.

Another interesting question is the clinical relevance of superimposed MS or MS with heterogeneous pigmentation that have been very rarely reported. ${ }^{11-13}$ This finding makes the presented case even more intriguing. As far as we are aware this is the first case reported in a caucasian infant. Histologically MS are characterized by spindle-shaped melanocytes in the lower layers of the dermis. The possible explanation for superimposed MS is the existence of different waves of melanocytic migration during embryogenesis resulting in different amounts of melanocytes in different layers of dermis. ${ }^{13}$ Superimposed MS have not been associated with abnormalities in the reported cases and their clinical relevance remains unknown. Misdiagnosis as markers of child abuse may happen, particularly with superimposed MS found in unusual sites. This situation was also excluded in our patient.

Further investigation is needed to support the association between aberrant MS and metabolism disorders and to define criteria and screening methods. If this correlation is proved in future, a workup for inborn error of metabolism will be applied to newborns with extensive Mongolian spots. Until then the authors recommend a careful clinical surveillance of atypical cases. The rarity of these cases and the multiplicity of diseases of metabolism with specific biochemical and genetic diagnostic exams do not currently justify their exhaustive investigation in all cases of atypical MS when other symptoms or signs are absent. For this reason this child maintains only clinical follow-up in the Pediatric Dermatology consultation.

New cases of aberrant or superimposed MS should be documented in order to improve our knowledge about these topics.

Conflitos de interesse: Os autores declaram não possuir conflitos de interesse.

Suporte financeiro: O presente trabalho não foi suportado por nenhum subsídio ou bolsa.

Confidencialidade dos dados: Os autores declaram ter seguido os protocolos do seu centro de trabalho acerca da publicação dos dados de doentes.

Protecção de pessoas e animais: Os autores declaram que os procedimentos seguidos estavam de acordo com os regulamentos estabelecidos pelos responsáveis da Comissão de lnvestigação Clínica e Ética e de acordo com a Declaração de Helsínquia da Associação Médica Mundial

Conflicts of interest: The authors have no conflicts of interest to declare.

Financing Support: This work has not received any contribution, grant or scholarship.

Confidentiality of data: The authors declare that they have followed the protocols of their work center on the publication of data from patients.

Protection of human and animal subjects: The authors declare that the procedures followed were in accordance with the regulations of the relevant clinical research ethics committee and with those of the Code of Ethics of the World Medical Association (Declaration of Helsinki). 


\section{Caso Clínico}

\section{REFERENCES}

1. Bishop JA. Melanocytic Naevi and Melanoma. In: Harper J, Oranje A, Prose N. Harper's Textbook of Pediatric Dermatology. $3^{\text {rd }}$ ed. Oxford: Blackwell Science; 2011 .p. 109.22.

2. Hanson M, Lupski JR, Hicks J, Metry D. Association of dermal melanocytosis with lysosomal storage disease: clinical features and hypotheses regarding pathogenesis. Arch Dermatol. 2003; 139:916-20.

3. Ochiai T, Suzuki Y, Kato T, Shichino $H$, Chin M, Mugishima $\mathrm{H}$, et al. Natural history of extensive Mongolian spots in mucopolysaccharidosis type II (Hunter syndrome): a survey among 52 Japanese patients. J Eur Acad Dermatol Venereol. 2007; 21:1082-5.

4. Ashrafi MR, Shabanian R, Mohammadi M, Kavusi S. Extensive Mongolian spots: a clinical sign merits special attention. Pediatr Neurol. 2006; 34:143-5.

5. Hackbart BA, Arita JH, Pinho RS, Masruha MR, Vilanova LC. Mongolian spots are not always a benign sign. J Pediatr. 2013; 162:1070.

6. Kumar BN, KheraD. Mongolian Spots in GM1 Gangliosidase. Indian Pediatr. 2016; 53:1133.

7. Mimouni-Bloch A, Finezilber $Y$, Rothschild M,
Raas-Rothschild A. Extensive Mongolian spots and lysosomal storage diseases. 2016; 170:333-e1.

8. Hall BD, Cadle RG, Morril-Cornelius SM, Bay CA. Phakomatosis pigmentovascularis: implications for severity with special reference to Mongolian spots associated with Sturge-Weber and Klipple-Trenaunay syndromes. Am J Med Genet A. 2007; 143A:3047-53.

9. Torrelo A, Zambrano A, Happle R. Large aberrant Mongolian spots coexisting with cutis marmorata telangiectatica congenita (phacomatosis pigmentovascularis type $\mathrm{V}$ or phacomatosis cesiomarmorata). J Eur Acad Dermatol Venereol. 2006; 20:308-10.

10. Wolf R, Wolf D, Davidovici B. Phacomatosis pigmentopigmentalis: aberrant Mongolian spots and segmental café au lait macules. Pediatr Dermatol. 2009; 26:2289.

11. Gupta D, Thappa DM. Mongolian spots - a prospective study. Pediatr Dermatol. 2013; 30:683-8.

12. Leung AK, Robson WL. Superimposed Mongolian spots. Pediatr Dermatol. 2008; 25:233-5.

13. Musumeci ML, Lacarrubba F, Santagati C, Micali G. Multiple and superimposed Mongolian spots. BMJ Case Rep. 2013; pii: bcr2013200740. 